\title{
Outsourcing And Off-Shoring: Options For The US Construction Industry
}

Anoop Sattineni, Auburn University

\begin{abstract}
The construction industry relies on the skills of structural engineers for all projects. There exists a large volume of design and detailing work for structural engineering in the United States (US) and there are insufficient numbers of qualified designers in the US to do the work. Recent changes in the telecommunications sector make off-shoring structural design work to developing countries like India and China a realistic possibility. Economics of outsourcing is a key reason for this possibility to be realized. It is logical to consider the effects of outsourcing in the design sector and its effects on the construction industry. The manuscript will present the author's finding based on detailed case-study model research with two companies that are outsourcing work to India from the US. The author conducted detailed interviews with principals in US structural design firms and then traveled to Bangalore, India to interview their Indian counterparts. Results from these interviews are presented. The author will present an empirical model for outsourcing construction activities. Processes in the construction industry that are most suited for outsourcing and off-shoring are presented. Issues surrounding outsourcing such as training, economics and logistics are discussed.
\end{abstract}

\section{INTRODUCTION}

$\mathrm{n}$ the past decade outsourcing and off-shoring have become prevalent practices in many industries. White collar jobs that were hitherto considered to be stable are now being outsourced to companies located in developing countries such as India and China. Information technology sector has invested heavily in the past ten years in developing countries (Dossani \& Kenny, 2007) and makes outsourcing a realistic opportunity. There exist many reasons for the dramatic increase in outsourcing and off-shoring of US jobs to developing countries. Economics is perceived as the most important reason for this trend; however several reasons exist for outsourcing and off-shoring (Quinn, 2000). The New York Times columnist Thomas Friedman's book "The World is Flat" has sparked public debate about the role of America in the evolving business world. The benefits and pitfalls of outsourcing and off-shoring are vigorously debated at many levels of government and media in the US (Bryant, 2006).

The Information Technology (IT) sector has been increasingly off-shoring work to developing countries in Asia, particularly India over the last decade (Arora \& Athreye, 2002 \& D'Costa 2002). The cost of a skilled worker doing computer programming job in India can be as little as a tenth of the cost of hiring the same worker in the US. The primary reasons for the availability of cheap labor are the differences in currencies, cost of living and the availability of a plethora of suitable candidates for jobs. China and India combine to produce almost a million engineers a year compared to the 70,000 engineers produced in the US. While economics are an important part of the justification for outsourcing, there existed a need for the IT sector to outsource as there was a scarcity of skilled workers from the early to the late 90 's. The US government has issued as many as 185,000 visas per year to highly skilled foreign workers mainly catering to the Information Technology sector. These numbers still did not meet the demand for workers in the IT sector. Eventually this forced companies to set up shop in developing countries and do the work off-shore. The need for workers might have prompted the outsourcing and off-shoring business model but today companies look to gain a competitive advantage by trying to align themselves with a global workforce comprising of the brightest minds in the world. Thomas Friedman in his book famously quoted that 'There are more honor students in China than students in America'. This global workforce is seen as a key to innovation in several 
industries. Apart using developing countries in Asia as an outsourcing outlet, the Information Technology industry is also widely credited for the revival of the Irish economy by means of outsourcing and off-shoring.

'Business Process Outsourcing' (BPO) in the last few years has lead corporations in the US to off-shore a myriad of back office work such as human resources, accounting, auditing, advertising, telemarketing and customer relations to India and other countries. The BPO sector in India in 2007 is projected to have 800,000 employees as compared to less than 100,000 in 2000 (Dossani \& Kenney, 2004). Even the healthcare industry has instances of outsourcing radiological services to India (Goelman, 2005). Companies are keen to identify processes that are best suited for state side employees and processes that might be performed by an off-shore staff and thus increasing their overall productivity.

The decreased cost of telecommunications is an important reason for the rise of the outsourcing and offshoring business models. The cost of transferring a megabyte of information from the US to India went from fifty dollars in 1996 to almost zero in 2000 (Grove, 2003). The low cost of communication and the difference in time zones between India and the US meant that companies could work around the clock with the workforce split between different continents.

\section{AEC INDUSTRY BUSINESS PROCESSES}

The Architecture, Engineering and Construction (AEC) industry has seen aspect of their business processes being outsourced in the past decade. Several engineering firms in the US have adopted the off-shore business model. Multiple versions of the outsourcing / off-shoring business model exist. A typical model is where structural design work is performed in the US. Once the design work is completed, detailed drawings are required for the manufacturer to produce the material (Patwardhan, 2004). This is done by a specialist known as a 'detailer'. The detailing work is increasingly outsourced or off-shored to companies in India or other developing countries. Structural engineering firms either outsource this work to another firm or have a detailing unit within their firm. Structural engineering firms that house a detailing unit are increasingly moving to an off-shore model.

In the architecture sector some common forms of outsourced work are prevalent. An architecture firm may provide concept drawings to its outsourcing partners and contract out the development of detailed drawings. Three dimensional walkthroughs and renderings, development of a digital model using building information modeling tools and conversion of paper based drawings to digital format are also being outsourced.

\section{METHODOLOGY}

As part of this case-study detailed interviews were conducted of two engineering firms. To maintain the anonymity of the firms they will be referred to as company A and company B. The interviews provided a glimpse of lessons learned by these engineering firms and will be used in the development of an empirical outsourcing model for construction.

Company A: This firm is based in Alabama. It is a structural steel supply and installation firm. Company A has a detailing office in Bangalore, India. They have four project managers in their US operations and have 20 engineers in their Bangalore office. Detailed interviews of the company A's principal in the US and their counterparts in India were conducted. Interviews of engineering staff in their India office were also conducted. Company A has an outsourcing type relationship with their counterparts in India. The office in Bangalore operates as its own entity under a different name but works exclusively for company A. The Indian counterparts for Company A started with creating shop drawings as a starting point for getting things off the ground. This activity still dominates a majority of the work that is sent to their Indian partners. This relationship continues to grow as the engineering firm in India is now taking on structural steel design and timber design work on behalf of company A.

Company B: This is a large engineering firm based in Tennessee. Company B provides services for structural engineering and detailing, transportation engineering, precast concrete engineering and land civil engineering. Company B has several offices in the US and also has an office in Bangalore, India. The office in India 
operates on an off-shore model as it operates under its own name, as a global entity. Company B has 35 engineers in the US and has 150 engineers in their Bangalore office. The office in Bangalore has personnel in all faculties of company B's expertise. Company B's CEO was interviewed in this study along with the manager of operations for their Indian office. This company is also venturing to providing cost estimating services to construction companies. Their aim is to provide these estimating services with their offshore personnel in India serving as champions in the effort.

\section{RESULTS}

The visits to the engineering companies in India provided information on several issues about outsourcing to India. These issues are broadly categorized and addressed below.

\section{Getting Started}

The idea of outsourcing came about in the late nineties to both companies. Companies A and B reported in the same words by saying "We did not know where to start". The first task both companies undertook was to hire their offshore partners and start looking at processes that might be suitable for getting started. The principals of both companies expressed that while they hired competent people on paper, the level of expertise in US methods was an unknown factor in this endeavor. They both expressed excitement and despair at finding out that their Indian counterparts had solid knowledge of engineering principles but had the disadvantage of not knowing the AEC business processes and practices of the United States. Identifying training as the first priority was the consensus based on the interviews with principals of companies of A and B.

\section{Training}

The first thing that became apparent to both companies was that their Indian counterparts needed training in some basic nomenclature that might be considered common knowledge in the US. Training in both instances started with some rudimentary terms that are common to the AEC industry. An example of this is the case of \#5 rebar. A \#5 rebar indicates that the diameter of the bar is five-eighth of an inch. This information is considered very trivial in the US AEC industry but it did not make any sense to a construction professional with a degree in civil engineering from a reputed university in India. There were several instances of the $\# 5$ bar in the initial stages of this partnership. Company A started making a list of basic terms to get things started and later educated their Indian counterparts in more complicated issues of engineering design and codes. Company B started creating a library of both digital and physical resources. Company B created a repository of images and transferred actual physical specimens of the \#5 bars and other physical specimens to their Bangalore offices to serve as training aids for future employees. To aid in training Company A and Company B brought key personnel from India to their offices and job-sites in America. Interviews with staff in India indicated that these visits were very beneficial in understanding the business processes and practices.

Structural engineering design in the US is regulated by code governing agencies such as 'American Institute for Steel Construction (AISC)', 'American Society for Civil Engineers (ASCE)', 'American Concrete Institute (ACI)' and 'Universal Building Code (UBC)'. These organizations publish extensive manuals for the proper use of building materials and methods of construction. These manuals were used by both companies to train their personnel in India. The AISC produces extensive video tutorials for the generation of shop drawings for structural steel. Since this was the first activity both firms started with, video tutorials worked very well in the training processes. University level text books were also used by the companies. Company A went a step further by paying for an academician to travel to India and teach their Indian staff for a few weeks to get things started. However, it was described by the CEO of company A that sending an academician was not completely successful since the academician was not well versed with the processes within the company.

There was significant investment from both companies to get things started especially by way of training. During the training phase it was indicated that all work was done twice, once in India and once in the US to ensure 
that the training is effective. This put a strain on resources for both companies and the principals of these firms stated that the commitment for making this partnership work was a key to success.

\section{Communication}

The most important aspect of creating and nurturing a successful long distance relationship is communication. Effective communication is especially important considering that there are only few hours during the day when personnel were working in offices both in the US and India. The tools of communication are ever changing with advancements in communication technology. The cost of communication itself has dropped exponentially in the past few years due to broadband networks. 'Instant Messengers', 'Chat Rooms', 'Video Conferencing', 'Remote Desktop' are the tools of choice for communication in both companies and have replaced the conventional telephone line.

Project information is typically transferred back and forth between offices in India and US exclusively in digital formats. Each day begins for personnel in the US to get an update of the work done in India during the night. The staff in India comes to work with a 'To Do List' provided by their supervisors in the US. The cost of transferring data from India to US has dropped dramatically and is no longer a limiting factor. While the size of the two companies interviewed varied greatly the author found it unexpected to see that staff in both offices were using the same communication tools such as 'Yahoo Instant Messenger'. To enable in communication it is customary in both companies for team leaders in India to start the day around mid-day and work late and for their partners in US to start the day early and finish early. A disadvantage listed by employees in India was this difference in the time zones. The staff mentioned that too frequently they were unable to spend time with their families as the work day ended late. Staff in India and the US mentioned that they learned about each other's cultures better by working together. Companies tried to schedule work around popular festivals and holidays unique to India such as 'Diwali'. One theme that was mentioned several times by all participants during the interviews was the 'Commitment to Communication'.

\section{Productivity}

Several factors affect the productivity of a company that is off-shoring work to India. Finding and retaining good detailers in the US was described by both company principals as an arduous task. In India these companies had the opposite problem of turning people away since they had more than 30 people to interview for each position they were trying to hire.

One major issue is the availability of inexpensive and qualified labor. As mentioned earlier the cost of hiring staff in a third world country such as India is significantly less than hiring he same worker in the US. A steel detailer in the US is paid about \$25 an hour compared to around \$6 in India. Another factor in improved productivity is the qualification of the employees. A steel detailer in the US typically goes to trade school and has an Associate's degree in that field. A steel detailer in India typically has a bachelor's degree in civil engineering, typically from a reputed school. By hiring qualified workers to do what might be considered lower level jobs, both companies found that work was done accurately with fewer errors and done faster. The high quality of candidates hired in their offices in India resulted in increased innovation for companies A and B. An example of this is the use of structural engineering software program by company B. The software was used by the company to design structures for gravity loads only and not used for designing for lateral loads. The staff in India learned and used these features in the software and later taught it to their partners in India.

Software programs for engineering design and detailing are very expensive. An aspect of improved productivity is the use of software license servers. By sharing software licenses, companies A and B are able to ensure that software is being utilized for more hours in a day by having offices in different time zones. 


\section{Growth}

Both companies interviewed in this study had extensive growth in their operations in India as well as growth in their US business volume. In India, company A went from four employees to twenty employees within six years while company B went from five employees to one and hundred and fifty employees within seven years. The growth in these companies is an indication of the success they have had in the off-shoring venture and also indicates the growth in productivity of the companies. Economies in developing countries such as India and China are growing at double digit rates and the growth seen in these companies is comparable to the growth in the economy of India.

\section{Risk}

It is important to understand that out-sourcing and off-shoring inherently bring some aspects of risk. Several reasons contribute to this risk. Company A has 5 project managers in their US office and 20 engineers in their Bangalore office while company B has 35 engineers in the US compared to 150 in the Bangalore. These numbers indicate that a majority of the work is done outside the US. The political climate in the US is much more stable compared to that of India. India and the US enjoy a cordial relationship at the business and government levels. However that is not an indication that it will continue to remain so forever. An example of this is when sanctions were placed on India immediately by the US due to nuclear weapon testing during 1998, which affected businesses in both countries. Situations of this nature are unpredictable and can lead severe consequences for US companies. The state of differences in infrastructure is also more stable in the US compared to that of developing countries. An example of infrastructure is that of 'Power Cuts' in developing countries. It is not uncommon in cities of India to have scheduled power cuts during peak consumption hours. As these developing countries grow, the demand for energy will outgrow their supply. This poses risks to the companies in the US where projects may be delayed due to power supply interruptions in Bangalore or such cities.

An important aspect of risk is the growth rate of employee salaries in India. Salaries in companies A and B increase at about $15 \%$ to $20 \%$ per annum for staff in their Bangalore offices. If this rate of growth for salaries continues in India, it is conceivable that cost of hiring an employee in India might not be significantly different from that in the US. Salaries in the information technology are typically higher than those of other sectors in India. Shortage of computer science graduates in India has driven companies to recruit students from disciplines like civil and mechanical engineering to do software programming jobs. The executives in companies A and B believe that this can be an issue that might hurt recruiting in India in the long term.

\section{ISSUES TO CONSIDER FOR OUTSOURCING AND OFF-SHORING IN CONSTRUCTION}

It is a commonly believed economic principle that 'goods will be made where it is most economical to make them'. The service industry in the US has come to realize that it is true for service sector jobs as well. This is highlighted by the number of service jobs that are increasingly being out-sourced and off-shored. The construction industry is closely aligned with architecture and engineering. The issues understood from the company visits in India provided the author with important perspectives in developing a plan for construction companies to outsource their business processes.

It is evident from intuition that training would be an important part of any off-shoring / outsourcing venture. This was confirmed from the company visits described earlier. Constructions companies that are interested in outsourcing must first identify business processes that are best suited for outsourcing. Construction requires personnel in the field and requires managers that are intimately aware of the conditions on the field. Therefore it is unlikely that field based operations will suite outsourcing. Pre-construction services are an area that might suite outsourcing. Certain pre-construction services such as estimating can be done without interacting with the client or others within the company. Building Information Modeling (BIM) is an aspect that is increasingly talked about as the future of the AEC industry. A BIM model is a computer model and can be built irrespective of the geographic location of the modeler. This activity can easily be outsourced. Accounting is another aspect that can be performed without any relation to geographic location and can be outsourced. Construction companies increasingly do their 
work through web-based project management programs that require extensive upkeep. This is another example of outsource-able work. These activities will most certainly be the beginning of outsourcing and will likely lead to other activities being outsourced as companies get more comfortable with their business models.

The following three models of out-sourcing and off-shoring are proposed by the author for construction.

\section{Joint Venture Outsourcing}

In this model a company from the US will choose a construction company and partner with them to outsource business processes. Estimating, as described earlier can be done irrespective of the physical location. Since estimating is a process done by all construction companies in the world, partnering with a construction company in a developing country to produce estimates in digital format may be outsourced. The training of employees can be easier since employees in the off-shore construction companies are already versed in various aspects of construction. However since construction in the US is different, some amount of training will still be required.

\section{Individual Project Off-Shoring}

A construction company can choose to outsource specific processes to a company in a developing country on a one-time or a project by project basis. A typical activity could include outsourcing of a BIM model that could be developed by the company for a negotiated fee. This format can also be used for outsourcing of processes such as estimating and upkeep of web-based project management systems. The company hired to do such work must already possess the knowledge required to perform the outsourced tasks.

\section{Global Delivery Off-Shoring}

In this model a construction company would hire workers in a developing country, and train them to perform tasks from a remote location, as was the case in the engineering companies visited by the author. This model will require the construction company the most opportunity for cost savings but also has the most risk. The risk exists since the infrastructure investment in the early stages of this plan will be higher than that of the other two models. The construction company will have to go to these developing countries to hire workers in that market and possibly bear the expenses of sending someone from their US office to run the day-to-day operations, at least during the early stages. This model also enables the construction company to train their off-shore personnel in methods that are consistent with the parent company.

\section{CONCLUSIONS}

Outsourcing and off-shoring has quickly become a theme in all businesses across the map. The number of sectors of business involved in this trend is ever increasing as described in this paper. This trend is unlikely to change and will only continue to grow due to the economic reasons behind it. The AEC industries are also making inroads towards in this direction. Outsourcing of civil engineering services and certain architectural services is not uncommon. The construction industry, by nature, has many processes that are not suited for outsourcing. Some tasks such as estimating and BIM modeling can be outsourced. The observations from visiting two engineering firms with offices in India provided the author insight to create a model for outsourcing in construction. The author indentified three factors that lead to the success of these two engineering firms which was a key to their success. Both companies did not anticipate or foresee the full benefits of outsourcing when they started the process. That was gamble that seemed to have paid off for companies A and B. Communication and training were another factor, key to success of these companies. And finally, both companies stressed on the commitment to make this partnership work and that commitment was the cornerstone of their success in later years. This manuscript also identified three outsourcing models for construction companies, namely 'Joint Venture Outsourcing', 'Individual Project Outsourcing' and 'Global Delivery Off-Shoring'. 


\section{REFERENCES}

1. Arora, A and Suma A. 2002. The software industry and India's economic development. Information Economics and Policy. 2002 - Vol. 14, No. 2 p. 253

2. Braynt, P. 2006. Decline of the Engineering Class: Effects of Global Outsourcing of Engineering Services Leadership and Management in Engineering. April 2006. pp 59-71

3. D'Costa, A. 2002. Uneven and Combined Development: Understanding India's Software Exports. World Development, Vol. 31, No.1, 211-226

4. Dossani, R and Martin K. 2007. The Next Wave of Globalization: Relocating Service Provision to India World Development Vol. 35, No. 5, pp. 772-791

5. Dossani, R and Martin K. 2004. Lift and Shift: Off-shoring and Outsourcing of Service Activities Presentation at conference on Global Sourcing and Regions of Innovation, UCSC Silicon Valley Regional Center, April 30, 2004.

6. Dossani, R and Martin K. 2004. Went for Cost, Stayed for Quality? Moving the Back Office to India, Asia Pacific Research Center, Stanford University.

7. Grove, A. 2003. The Coming Software X Curve. Presentation to the Business Software Alliance, October 9, 2003

8. Levy, F and Goleman, A. 2005. Off-shoring and Radiology Brookings Trade Forum 2005. $411-423$.

9. Patwardhan, R. 2004 Distance Engineering: New Trends in Structural Engineering The Indian Concrete Journal. February, 2004

10. Quinn, J. B (Summer, 2000). Outsourcing Innovation: The New Engine of Growth Sloan Management Review, Summer 2000. 


\section{NOTES}

